Article

\title{
Implications of Frugal Innovations on Sustainable Development: Evaluating Water and Energy Innovations
}

\author{
Jarkko Levänen ${ }^{1, *,+}$, Mokter Hossain ${ }^{2, \dagger}$, Tatu Lyytinen ${ }^{1, \dagger}{ }^{,}$Anne Hyvärinen ${ }^{3}$, Sini Numminen ${ }^{2}$ \\ and Minna Halme ${ }^{1}$ \\ Received: 18 November 2015; Accepted: 18 December 2015; Published: 23 December 2015 \\ Academic Editor: Andrew Kusiak \\ 1 School of Business, Aalto University, P.O. Box 11000, FI-00076 Aalto, Finland; tatu.lyytinen@aalto.fi (T.L.); \\ minna.halme@aalto.fi (M.H.) \\ 2 School of Science, Aalto University, P.O. Box 15500, FI-00076 Aalto, Finland; mokter.hossain@aalto.fi (M.H.); \\ sini.numminen@aalto.fi (S.N.) \\ 3 School of Engineering, Aalto University, P.O. Box 15500, FI-00076 Aalto, Finland; anne.hyvarinen@aalto.fi \\ * Correspondence: jarkko.levanen@aalto.fi; Tel.: +358-50-463-9202 \\ + These authors contributed equally to this work.
}

\begin{abstract}
Frugal innovations are often associated with sustainable development. These connections, however, are based on anecdotal assumptions rather than empirical evidence. This article evaluates the sustainability of four frugal innovations from water and energy sectors. For the purposes of the evaluation, a set of indicators was developed. Indicators are drawn from sustainable development goals by the United Nations and they encompass central dimensions of sustainability: ecological, social and economic. In this article, frugal innovations are compared to solutions that are currently used in similar low-income contexts. Studied frugal innovations were found more sustainable in terms of energy production and water purification capacity than the existing solutions. In terms of social sustainability, larger differences between innovations were found. For example, business models of frugal energy solutions focus on capacity building and the inclusion of marginalized low-income people, whereas business models of water purification solutions focus on more traditional corporate social responsibility activities, such as marketing awareness campaigns and cooperation with non-governmental organizations. Three major sustainability challenges for frugal innovators were identified: (1) the proper integration of material efficiency into product or service systems; (2) the patient promotion of inclusive employment; and (3) the promotion of inclusive and sustainable local industrialization. The article concludes that despite indisputable similarities between frugality and sustainability, it is problematic to equate the two conceptually.
\end{abstract}

Keywords: sustainability; frugal innovation; SDG; evaluation; indicators; water; energy

\section{Introduction}

Frugal innovation is a recently emerging concept [1-3]. It refers to solutions created under the circumstances of resource constraints. It is driven by demand, imitation and low-cost competition in emerging markets where enterprises are developing new resource-scarce solutions for low-income and rising middle-income segments [1,4]. Frugal innovations address problems in various sectors, such as healthcare, water, energy, transportation and communication, by involving the private sector $[3,5,6]$. A study by Rao [7] argues that frugal innovations typically consist of characteristics, such as few essential features, low-cost, an emphasis on local use, local and discarded materials, simple usability and the minimum amount of resources. Frugality has also been seen as a characteristic of sustainable 
behavior or lifestyle [8,9]. Because of these types of notions, it is common to assume frugality to equate to sustainability [10]. Yet, the exact conceptual or empirical connection between frugality and sustainability has not been previously investigated. In order to assess whether the claim that frugality advances sustainability is justified, in this paper, we explore the sustainability implications of frugal innovations from an empirical vantage point.

Ever since the sustainable development concept was introduced in the late 1980s, it has been implemented into different spheres of global policy-making. Although widely applied, it is a much debated and contested concept [11]. Some experts consider sustainability a vague concept, and its scientific definition, as well as its measurement have been disputed [12]. In this study, we adhere to the definition of the World Commission on Environment and Development, also known as the Brundtland commission: "Sustainable development is development that meets the needs of the present without compromising the ability of future generations to meet their own needs" [13]. In practice, sustainable development is a transformation process whereby societies move toward sustainability in three dimensions: ecological, social and economic. In the attempt to operationalize the idea of sustainable development and make it more conducive to action, a variety of political goals and principles have been drafted, the Millennium Development Goals (MDGs) set by the United Nations being perhaps the most robust example. Recently, a multi-stakeholder high-level negotiation process managed to construct Sustainable Development Goals (SDGs), which will replace MDGs. For the purposes of this study, we adhere to SDGs, as we find them action-oriented, concise and easy to communicate, as well as helpful for the implementation of sustainable development [14].

In previous literature, resource scarcity has traditionally been seen as a constraint for innovation activities, and responses to these scarcities have been conceptualized through such terms as bricolage and improvisation $[15,16]$. The concept of frugal innovation takes another view on resource scarcity and sees it as an opportunity. Frugal innovations are receiving increasing attention from scholars, practitioners and policy makers. These innovations are developed by multinationals, social enterprises, startups and individuals from developed and developing countries $[1,7,17]$. They are considered a solution for tackling sustainability concerns in low-income countries, because they address affordability, accessibility and availability, which are major issues, especially in developing countries [18-20]. Even though frugal innovations are loosely argued to promote sustainability $[5,18,19,21]$, the current academic literature and popular press are largely devoid of any analysis of the implications of frugal innovations for sustainability [22]. Consequently, a number of articles suggest analyzing frugal innovation with the aid of the lens of sustainability $[7,22]$.

In this paper, we start closing the gap by empirically studying the degree of the sustainability of four frugal innovations from the water and energy sectors. As stated, SDGs provide a pragmatic way to approach sustainability analytically. We propose that if a particular activity promotes SDGs, then the activity can be considered sustainable. Respectively, if it is possible to point out that a particular frugal innovation is capable of promoting issues that are reflected in the indicators of SDGs, then this indication signals the sustainability of that frugal innovation. The official negotiation process on SDGs triggered discussions among experts about the appropriateness of SDGs for measuring sustainability. Hence, we also contribute to these discussions by evaluating the appropriateness of indicators that have been retrieved from the SDGs.

We compare frugal innovations against solutions that are currently used in low-income contexts, not against other products available in the markets. The remainder of the paper is structured as follows. The next section describes the data collection, analysis and research techniques along with four cases. The analysis and findings are presented in Section 3. Thereafter, we discuss the implications and future research directions in Section 4, before drawing our conclusions in Section 5. 


\section{Data and Methods}

\subsection{Criteria to Evaluate Sustainability}

In this study, we focus on the implications of frugal innovations for sustainability in the user environment at the local level. We measure the capacity of frugal innovations to promote Sustainable Development Goals (SDGs; presented in Appendix 1). As a tool for the analysis, we use a set of nine indicators that: are (1) drawn from SDGs; and (2) capable of measuring the sustainability of frugal innovations from energy and water sectors in ecological, social and economic dimensions. Three indicators measure sustainability in each dimension, and all indicators are weighted equally. In Table 1 , we present the indicators and identify the SDGs from which each indicator is drawn. The basic idea is that the indicators comprise themes that are described in SDGs into quantifiable measures that are compatible with the analyzed frugal innovations. To maintain the applicability of the indicators for the purposes of this analysis, we interpreted the themes of SDGs rather loosely. For example, we assume that sustainable consumption and production patterns (SDG 12) promote material efficiency (Indicator 2), and the creation of jobs (Indicator 9) makes it possible to tackle poverty (SDG 1). Each indicator contains similar types of assumptions.

Table 1. Indicators for the analysis of the sustainability of frugal innovations.

\begin{tabular}{clc}
\hline No. & Sustainability Indicators for Frugal Innovations & $\begin{array}{c}\text { Indicators Based } \\
\text { on the SDGs }\end{array}$ \\
\hline Ecological sustainability indicators & $7,9,15$ \\
\hline 1 & $\begin{array}{l}\text { Is the frugal innovation more energy efficient than } \\
\text { the existing solution? }\end{array}$ & $9,12,15$ \\
\hline 2 & $\begin{array}{l}\text { Is the frugal innovation more material efficient, e.g., } \\
\text { recyclable or reusable, than the existing solution? }\end{array}$ & $9,11,13$ \\
\hline 3 & $\begin{array}{l}\text { Is the frugal innovation more climate neutral than } \\
\text { the existing solution? }\end{array}$ & $1,2,6$ \\
\hline Social sustainability indicators & $1,4,10,11,16$ \\
\hline 4 & $\begin{array}{l}\text { Does the frugal innovation help to fulfill basic } \\
\text { necessities, such as water, food or shelter? }\end{array}$ & \\
\hline 5 & $\begin{array}{l}\text { Does the frugal innovation enable better health or } \\
\text { improve access to education? }\end{array}$ & 7,16 \\
\hline 6 & $\begin{array}{l}\text { Does the frugal innovation increase the inclusion of } \\
\text { marginalized people in society and/or equality } \\
\text { between its members? }\end{array}$ & $1,6,7$ \\
\hline Economic sustainability indicators & $\begin{array}{l}\text { Does the use of the frugal innovation release the time } \\
\text { resources of the users for other purposes? }\end{array}$ \\
\hline 8 & $\begin{array}{l}\text { Does the use of the frugal innovation increase the } \\
\text { income of the user or save them money? }\end{array}$ & $\begin{array}{l}\text { Does the frugal innovation create new jobs and/or } \\
\text { new enterprises? }\end{array}$ \\
\hline 9 &
\end{tabular}

We recognize that the suggested indicators may not be compatible as such with the analyses of frugal innovations from other sectors or industries. Neither is it possible to measure all SDG themes by means of the above set of indicators. The themes addressed by our indicators only cover the aspects of sustainability that are relevant from the perspectives of the studied frugal innovations. This article exemplifies a way of translating selected SDG themes into a set of indicators.

\subsection{Selection of Cases for the Analysis}

We adopted a systematic approach to identifying cases that are claimed as frugal innovations in the existing literature [23]. Using frugal innovation as a search term in the databases of the Web of Science, Scopus, EBSCO (Elton B. Stephens Co.), Google Scholars and SSRN (Social Science Research 
Network), all articles were downloaded in a temporary folder. The search was performed in the last week of May 2015. This search resulted in 115 articles and three book chapters. Each publication was carefully read to ensure their focus on frugal innovation. Publications that were not focused on the frugal innovation phenomenon were left out. We know that additional cases, which resemble frugal innovations in different ways, but are not called as such, may be found in the literature. In this study, however, we only took into account cases that are explicitly referred to as frugal innovations.

Thirteen articles did not mention frugal innovation cases, and three book chapters were inaccessible. Finally, 62 publications were found appropriate for the next stage. All cases mentioned as frugal innovations were extracted from these articles and listed in a spreadsheet. Subsequently, the frequency of the cases was calculated. The list of the 30 most frequently-cited frugal innovation cases is presented in Table 2. Altogether, we found 116 cases of frugal innovation mentioned in the literature; a total of 85 cases are mentioned only once and 20 cases twice.

Table 2. List of 30 most frequently-mentioned frugal innovations; bolded ones are selected into the analysis.

\begin{tabular}{cccc}
\hline Cases & Frequency & Sector & Country of Origin \\
\hline Tata Nano & 25 & Transport & India \\
GE's ECG machine & 20 & Healthcare & India \\
GE's Ultrasound machine & 13 & Healthcare & China \\
Aravind Eye Care & 10 & Healthcare & India \\
Tata Swach & 10 & Water & India \\
Aakash & 7 & ICT & India \\
M-Pesa & 7 & Bank & Kenya \\
Chotucool & 6 & Appliances & India \\
Husk Power Systems & 6 & Energy & India \\
MittiCool & 6 & Appliances & India \\
Narayana Hospital & 6 & Healthcare & India \\
Vortex ATMs & 6 & Bank & India \\
GE's Lullaby baby warmer & 5 & Healthcare & India \\
Jaipur foot & 5 & Healthcare & India \\
Mahindra \& Mahindra's small tractors & 5 & Transport & India \\
Embrace & 5 & Healthcare & USA \\
Grameen Bank's microfinance & 4 & Bank & Bangladesh \\
Easy Paisa & 4 & Bank & Pakistan \\
Haier's washing machine & 3 & Appliances & China \\
Logitech mouse & 3 & ICT & China \\
Bharti Airtel & 3 & ICT & India \\
Rickshaw Bank in India & 3 & Bank & India \\
SELCO & 3 & Energy & India \\
Nokia 1100 & 2 & ICT & Finland \\
Nokia's 101 & 2 & ICT & Finland \\
Vodafone Rs.10 pre-paid cellular phone & 2 & Bank & India \\
EKO mobile phone banking & 2 & ICT & India \\
Micromax Ace & 2 & Transport & India \\
Unilevers Purat & 2 & ICT & India \\
India & India \\
\hline Mabile phone (India) & 2 & &
\end{tabular}

\subsection{Data and Selected Cases}

From water and energy sectors, we selected those cases that were most frequently mentioned as frugal innovations in the literature. Frugal water and energy innovations were analyzed for their roles in sustainable development by using the above-introduced indicators (Table 1). It is important to note that we did not evaluate the degree of frugality of the selected innovations, but instead, we only analyzed the capacity of the frugal innovations to promote issues reflected in SDGs. The data on the four cases are collected from various sources, including academic articles, reports, newspaper articles and company websites. Table 3 summarizes the citations in the existing literature and the number of data sources for each case study. 
Table 3. Summary of data sources and citations.

\begin{tabular}{cccccc}
\hline The Case & $\begin{array}{c}\text { Case } \\
\text { Citations }\end{array}$ & $\begin{array}{c}\text { Academic } \\
\text { Articles }\end{array}$ & Reports & $\begin{array}{c}\text { Newspaper } \\
\text { Articles }\end{array}$ & Company Websites \\
\hline Swach & 10 & 3 & 4 & 6 & $\begin{array}{c}\mathrm{http://www.tataswach.com/} \\
\mathrm{http://www.tatachemicals.com/}\end{array}$ \\
\hline Pureit & 2 & 3 & 6 & 4 & $\begin{array}{c}\mathrm{http://www.pureitwater.com/} \\
\text { http://www.hul.co.in/ } \\
\text { http://www.unilever.com/ }\end{array}$ \\
\hline SELCO & 2 & 0 & 3 & 10 & $\mathrm{http://www.selco-india.com/}$ \\
\hline HPS & 7 & 2 & 6 & 13 & http://www.huskpowersystems.com/ \\
\hline
\end{tabular}

The evaluation of the cases proceeded in four stages. First, all of the researchers familiarized themselves with all of the available data. Second, one researcher did the initial analysis for each case by giving the values " -" for negative, " 0 " for neutral or unclear and " + " for a positive indication of the frugal innovation's capability to promote sustainability. Third, the initial analysis of each author was rigorously discussed in a group of all authors to firm up the values of the indicators with necessary adjustments. Fourth, the overall findings of the analysis were discussed in the group consisting of all authors and agreed collegially (see Appendix 2). Next we will briefly introduce the frugal innovations that were selected into the analysis.

\subsubsection{Husk Power System (Energy)}

Husk Power Systems (HPS) is a company based in Bihar, India, founded in 2007. HPS provides power to rural Indians using proprietary technology that has been developed by the firm to cost-effectively generate electricity using a biomass gasifier that creates fuel from abundant rice husk waste. HPS operates 35-100 kW mini-power gasification plants and electrifies off-grid villages in India. The cost of the service is about half the cost of the kerosene that most villagers use to power lamps that provide far less light than the compact fluorescent lights (CFL) bulbs distributed by the company. As of 2015, Husk Power Systems serves 200,000 people through its 84 plants in rural India.

\subsubsection{SELCO (Energy)}

SELCO, founded in 1995, is a solar energy system integrator and a social enterprise from India. A typical system consists of four 7-W compact fluorescent lights (CFLs), and the electricity is generated by a small photovoltaic (PV) module, which is usually mounted on the roof of a house. A lead-acid battery is used to store electricity to ensure uninterrupted power. The innovation lies in a business model whereby SELCO arranges micro-loans for low-income customers from local banks, such as Grameen Bank. SELCO has so far sold over 200,000 solar systems, primarily in Indian states, such as Karnataka, Gujarat, Maharashtra, Bihar and Tamil Nadu.

\subsubsection{Tata Swach (Water)}

Tata Swach, developed by Tata Chemicals of India, is a gravity-driven "table top" water purification device for households, and it does not require electricity or running water. It was launched in India in 2009 as one of the world's most inexpensive water purifiers. The treatment technology is based on rice husk ash and nanotechnology. The technology is incorporated in a replaceable "bulb", which comes with a lifetime of 1500 liters and 3000 liters. Tata Chemicals of India claims that non-electric Tata Swach is effective at eliminating bacteria and viruses from water for safe drinking. Tens of millions of Tata Swach purifiers have been sold, but it seems that it is still too expensive to reach the extreme poor people of the low-income market segment.

\subsubsection{Hindustan Unilever Pureit (Water)}

In 2008, Hindustan Unilever (HUL) launched the Pureit Classic water purifier in India. Pureit is a gravity-driven "table-top" water filtration system that does not require electricity or running water 
to function. The technology consists of a four-stage purification process, which includes a microfiber mesh for the removal of larger particles, a carbon filter for the removal of certain protozoan parasites, a chlorine dispenser "Germkill Kit" for disinfection and a carbon polisher to remove excess chlorine and chlorination by-products. The replaceable "Germkill Kit" is claimed to meet the strict international criteria of the U.S. Environmental Protection Agency (USEPA) for the removal of harmful viruses and bacteria. Like Tata Swach, Pureit has been sold to millions of middle-income or high-income customers in the low-income market segment.

\section{Analysis and Findings}

For evaluating whether frugal innovations promote sustainability at the local level, we needed to understand existing solutions that are available in similar circumstances in low-income contexts and compare frugal innovations against those. Many people in India do not have access to electricity, and the existing distribution grids in rural areas are often unreliable. Kerosene, firewood and dung are commonly used as fuels to meet various household energy needs. Moreover, diesel-generated power is used predominantly for agricultural, industrial and commercial purposes. These fuels are expensive and harmful for the environment, and their use leads to health problems because of indoor air pollution.

The water solutions were compared against a situation in which water is treated by boiling with liquid petroleum gas (LPG), charcoal, wood or other solid fuels. Boiling is the most common method for effective household water treatment, and when practiced correctly, it is one of the most efficient means for improving the microbiological quality of water. Nevertheless, boiling has disadvantages, such as the inefficient use of time, recontamination risk during storage, health risks due to a decline in indoor air quality, deforestation and carbon emissions.

The findings from our sustainability analysis are summarized in Table 4. Next, we will introduce the evaluations of the frugal innovations based on ecological, social and economic sustainability parameters.

Table 4. Summary of the findings.

\begin{tabular}{|c|c|c|c|c|}
\hline Case/Indicator & Swach & Pureit & Selco & HPS \\
\hline \multicolumn{5}{|l|}{ Ecological } \\
\hline $\begin{array}{l}\text { Is the frugal innovation more energy efficient than } \\
\text { the existing solution? }\end{array}$ & + & + & + & + \\
\hline $\begin{array}{l}\text { Is the frugal innovation more material efficient, e.g., } \\
\text { recyclable or reusable, than the existing solution? }\end{array}$ & - & - & 0 & 0 \\
\hline $\begin{array}{l}\text { Is the frugal innovation more climate neutral than } \\
\text { the existing solution? }\end{array}$ & + & + & + & + \\
\hline \multicolumn{5}{|l|}{ Social } \\
\hline $\begin{array}{l}\text { Does the frugal innovation help to fulfill basic } \\
\text { necessities, such as water, food or shelter? }\end{array}$ & 0 & + & + & + \\
\hline $\begin{array}{l}\text { Does the frugal innovation enable better health or } \\
\text { improve access to education? }\end{array}$ & 0 & 0 & + & + \\
\hline $\begin{array}{l}\text { Does the frugal innovation increase the inclusion of } \\
\text { marginalized people in society and/or equality } \\
\text { between its members? }\end{array}$ & - & - & + & + \\
\hline \multicolumn{5}{|l|}{ Economic } \\
\hline $\begin{array}{l}\text { Does the use of frugal innovation release the time } \\
\text { resources of the users for other purposes? }\end{array}$ & + & + & + & + \\
\hline $\begin{array}{l}\text { Does the use of the frugal innovation increase the } \\
\text { income of the user or save them money? }\end{array}$ & 0 & 0 & + & + \\
\hline $\begin{array}{l}\text { Does the frugal innovation create new jobs and/or } \\
\text { new enterprises? }\end{array}$ & 0 & 0 & + & + \\
\hline
\end{tabular}




\subsection{Ecological Sustainability}

\subsubsection{Energy}

Both of the energy solutions analyzed clearly contribute to creating access to affordable, reliable, sustainable and modern energy for all. In particular, they enhance access to reliable energy services, since the majority of the targeted users live in remote areas where there is no access to electricity or the existing grid connection is unreliable. HPS provides electricity for the whole community, while SELCO lanterns are mainly used in households and small enterprises. Electric lights also provide more stable source of light than candles and kerosene light.

HPS uses abundant rice husk waste to power a small biomass gasifier and significantly reduces kerosene and diesel use [24]. In addition to the fact that HPS takes advantage of biomass waste, it effectively utilizes the side-stream of its process [24]. On the contrary, SELCO recycles the used lead-acid batteries as part of the service contract [25], which is very important due to the harmful substances they contain. Moreover, SELCO collects compact fluorescent lamps (CFLs) and returns them to manufacturers for recycling [26]. However, we did not find any evidence in the literature regarding the recycling of system components or a comprehensive lifecycle material efficiency analysis of the bioenergy or solar systems.

At the local level, both solutions are more climate neutral than existing solutions. Other power options, such as kerosene lanterns and diesel generators, are inefficient and produce significantly more $\mathrm{CO}_{2}$ emissions. Regarding HPS, the kerosene savings cut greenhouse gas emissions by an estimated 125 tons/year $\mathrm{CO}_{2}$ equivalent per power plant when assessed as part of the Clean Development Mechanism (CDM) certification [27]. SELCO has installed 71,000 solar home systems, leading to a total annual reduction in $\mathrm{CO}_{2}$ emissions of 22,000 tons and a total annual savings of 120 liters of kerosene per family annually [25].

\subsubsection{Water}

Swach and Pureit are more energy efficient than existing solutions, as they do not require electricity or running water to function. However, according to external testing, the microbiological purification efficacy of Swach does not reach international standards [28]. Here, the efficacy is considered to be good enough, as water quality is measurably improved. External research has shown that Pureit reaches international standards for microbiological purification efficacy [29], and no additional measures for microbiological treatment are required.

Both Swach and Pureit offer a replaceable purification "bulb" or "kit" after every 1500 or 3000 liters, depending on the model [30,31]. Swach combines rice husk waste with a coating of silver nano-particles to filter water, and no chemicals are utilized in the purification process [32]. The Swach solution can be regarded as more reusable and material efficient than boiling with solid fuels, but it should be noted that there is no evidence of recycling initiatives for Swach or Pureit purifiers or their components, such as filters. Due to the generated wastes, both are considered to have a negative impact regarding material efficiency, reusability and recyclability.

The climate impacts of the water treatment solutions are indirect. However, boiling water, especially with solid fuels, results in carbon emissions. Moreover, making firewood causes deforestation in the areas where the renewability of forest ecosystems does not match the increasing demand for wood [33]. Consequently, both Swach and Pureit are considered more climate neutral than the existing solutions.

\subsection{Social Sustainability}

\subsubsection{Energy}

Frugal bioenergy solutions do not directly fulfill basic necessities, such as water, food or shelter. The main contribution of both solutions is that in certain situations, they enhance the security of a 
shelter, since light can be kept on [34]. Furthermore, the access to electricity provided by HPS indirectly supports the fulfillment of basic necessities by enabling more efficient water solutions, such as pumps, and improving cooking quality [34].

HPS and SELCO promote education and health. HPS has systematically focused on education, empowerment and increasing the capacity of local people to own, operate and maintain the plants and to help local women learn to utilize the side streams [35]. In addition, HPS supports the education of local children and the training of teachers by financial and other means [36]. Better health is strongly related to a reduction in the indoor pollution that was produced by kerosene lamps, while HPS also provides medical cover to its employees [24]. In part, having electric lights at home also improves learning opportunities and education, as children can study later in the evening.

Both solutions also increase a users' inclusion into society and equality between its members. HPS actively increases the inclusion of marginalized local people by providing empowerment and employment for local women and by recruiting locals with modest education levels [36]. HPS also encourages equality among employees and intends to reduce inequality caused by local caste systems [34]. SELCO strives to narrow the inequality among their customers, and the company arranges variable micro-loans and financing models for different customer groups [37].

\subsubsection{Water}

Swach aims to provide safe drinking water, but fails in fully achieving this due to shortcomings in microbiological treatment efficacy [28]. Therefore, its water quality can be regarded as being lower than that obtained by proper boiling. Still, the quality of the water Swach delivers is good enough for drinking, as it notably improves the quality of water compared to non-boiled water, thus fulfilling the basic need of safe water [38]. Pureit, instead, delivers safe water to its users, maintains international standards, fulfills a basic need and improves health [39].

Although both solutions are efficient in reducing the adverse effects of, for example, bacteria and viruses, from the water, they do not directly contribute in access to education or better health $[31,40]$. The use of filters instead of boiling improves indoor air quality, especially if solid fuel is used for boiling [33], which reduces health risks to women and children in particular. The companies also promote awareness as a part of their marketing strategy, by campaigning on the importance of safe and healthy drinking water $[38,41]$.

A direct link between water solutions and inclusion is difficult to establish. The original aim of Swach was to provide a water treatment alternative for low-income people. Unfortunately, the solution does not reach the poorest of the poor [40]. Recently, the Pureit purifier has become less expensive and thus more affordable for low-income people, as well, though its replaceable filters are still slightly more expensive than Swach's [30,31]. In collaboration with NGOs, Hindustan Unilever has donated Pureit devices to low-income people, but this is not considered to sustainably increase inclusion, as these initiatives tend to be one-off events. Additionally, selling or donating is not considered inclusive if marginalized people are not systematically included in the frugal innovation process.

\subsection{Economic Sustainability}

\subsubsection{Energy}

Both energy solutions release users' time for other purposes. Reliable electricity enables flexibility for commercial actors, and lightning increases the number of productive hours after dark for households [37,42]. Both HPS and SELCO provide electric lamps as a part of their solutions to replace kerosene lamps. Furthermore, people who did not have access to electricity can now charge their phones at home, and those who previously used diesel generators or kerosene lamps no longer have to travel to purchase fuel [42].

The solutions also increase the users' disposable income, as HPS and SELCO are economically more viable than existing diesel- and kerosene-based solutions, resulting in savings in energy 
costs [25,37]. Small-scale farmers, street vendors and other entrepreneurs are able to run their businesses in the evenings and, thus, increase their income [34,37]. The HPS solution uses local raw materials as a fuel for energy production, increases local economic activities [36] and improves the earning possibilities of the local people.

The energy solutions also create new jobs. HPS works on a build-own-maintain basis and hires and trains local people [43]. Local women are encouraged to work in the production of incense sticks [36]. SELCO employs hundreds of people in the villages, enabling the creation of further small companies that, for example, have set up solar light rental businesses [37]. Both HPS and SELCO products are manufactured locally in India $[37,39]$. Thus, they create jobs and promote industrialization and innovation. However, there was no evidence found that local poor people would benefit from these manufacturing activities.

\subsubsection{Water}

The water solutions release users' time when compared to boiling water. Both Swach and Pureit release time for the users as the systems purify the water "on their own". Thus, time is not wasted in collecting fuel for boiling or keeping an eye on the boiling. However, it should be emphasized that because the water treatment efficacy of Swach is insufficient, one should also deploy other methods, such as boiling, to attain water safety to the fullest.

It remains unclear whether either of the cases increases income or saves the money of low-income people. Although still too expensive for most low-income consumers, Pureit and Swach are significantly less expensive than the majority of the existing water purification solutions on the market [40]. It is unclear whether households can save any money by using Swach or Pureit instead of boiling their water, because it can be argued that people using collected firewood from their local environment are not making direct savings by using water filters. On the other hand, when people are using commercial firewood, charcoal or liquid petroleum gas (LPG), it can be claimed that it is less expensive to use Swach and Pureit than boiling water.

Even if both solutions require an active sales and marketing workforce, there is no evidence that either of the water solutions are aiming to generate jobs or new enterprises for low-income people. There are arguments that consumers can use some local materials to construct the filters or even manufacture them locally [40], but there is no evidence that this is happening in practice. Hence, Swach and Pureit are considered not to create new entrepreneurial business opportunities, even through existing kiosks can sell products.

\section{Discussion}

This study has explored the empirical and conceptual connections between frugality and sustainability. To that end, four frugal innovation cases were analyzed. Based on the findings made in relation to a set of sustainability indicators, we will next discuss the implications of this study.

A general observation is that the studied frugal innovations are more efficient in terms of energy production or water purification than existing solutions and are more climate neutral. The bioenergy and solar energy solutions are more efficient than existing fossil fuel-based kerosene and diesel solutions. However, it seems that bioenergy solutions are not more climate neutral than other renewable energy solutions, such as solar and wind [35]. The water purification solutions evaluated were more energy efficient than the existing solutions, which are based on boiling water with firewood or liquid petroleum gas.

Although there were some indications of material efficiency, such as recycling and reuse potential, the study did not provide sufficient evidence of increased material efficiency or the product's recycling was not addressed in a comprehensive manner. However, the solar energy provider showed the clearest indication, because the batteries are collected for recycling from the customers. The bioenergy solutions make use of otherwise harmful side-streams, but there was no indication of recycling for other parts of the solution. We assigned negative values to the water purification solutions' 
material efficiency, because there was no information on how the filters are recycled or reused, meaning the ecologically sustainability of these solutions is questionable. Similarly, there was no evidence of increased material efficiency from either a product lifecycle or circular economy perspective. Therefore, no positive values were given to the cases. Moreover, despite frugal innovations being more ecologically sustainable in a local context, it is especially difficult to estimate their material efficiency from the global life-cycle perspective.

Regarding water and shelter, the frugal energy and water innovations do contribute to fulfilling basic needs, and both energy solutions improve shelter safety and energy efficiency. Additionally, the energy solutions studied help to reduce indoor air pollution, and the water solutions improve the quality of drinking water. The energy solutions also indirectly support education by providing light for longer studying hours at night.

In relation to inclusion and access to education and health services, there was a clear difference between the energy and the water solutions. While both energy providers have evidently focused on capacity building and the inclusion of marginalized low-income people as part of their business model, water purification solution providers have focused on traditional corporate social responsibility activities, such as marketing awareness campaigns and cooperation with NGOs to donate purifiers to the poor people. This means that the energy cases we analyzed have a highly positive indication for promoting both inclusion and access to better health and education. In contrast, the water purification providers do not seem to make any difference to access to health or education, although safe water can contribute to better health. Moreover, the exclusion of the poor seems to increase in situations when new business activities are not offered by the system, such as tasks related to supply, production, marketing, sales and maintenance. The price of the water purifiers remains too high for the poorest of the poor. This is not to say that frugal energy solutions are more socially sustainable compared to frugal water solutions, as will be discussed later.

From the economic sustainability perspective, all of the studied frugal innovations release time resources for other purposes, especially because people do not need to travel long distances to obtain energy or water. Thus, with more efficient and reliable water and energy solutions, people can do other activities more efficiently, keep their shops open longer, farm more efficiently and have more time for household chores and leisure.

Frugal energy innovations save money for low-income people in two ways: (1) they offer less expensive electricity; and (2) they create income by employing local people and enabling new entrepreneurship. This means that a major part of the money saved and made is recycled back into the local economy. Similarly, the studied water solutions are less expensive than existing water purification devices on the market. However, compared to the existing solution for low-income people, i.e., boiling water, the studied water purification solutions are not significantly less expensive. Additionally, there is no evidence that water purification providers would have increased income or created new jobs or new enterprises at the low-income level.

It should be taken into consideration that the studied energy solutions were provided by social enterprises, whereas multinational companies (MNCs) provided water solutions. The energy solutions were developed by socially-oriented entrepreneurs who have addressed sustainability in a more comprehensive manner than the two corporations' water solutions. One reason for this orientation might be that both energy companies have relied on donor and development funding in the early stages of their journey: "Identifying funders who are interested in a social enterprise that serves the rural poor is not easy. In 2009, Husk received a pre-Series A round of financing from Acumen Fund, Bamboo Finance, LGT Philanthropy, Draper Fisher Jurvetson, and the International Finance Corporation (IFC) [35]". In contrast, it seems to be difficult for multinational companies to develop their products for the poorest of the poor. The reason for this might be that these markets are not seen as profitable or there are problems with international standards, especially when products are simplified too much: "As with many new and disruptive innovations, the Swach filter does not work 
as well as other similar products, nor does it satisfy the requirements of the professional bodies-in this case the World Health Organization (WHO) [40]".

In summary, the analyzed frugal innovations can be seen as more sustainable than existing solutions. At the same time, our analysis points out important limitations regarding the capacity of frugal innovations to promote sustainability. We identify three major sustainability challenges for frugal innovators: (1) the proper integration of material efficiency as part of the product or service systems (Appendix 1: SDG 12); (2) the patient promotion of local inclusive productive employment and decent work for all (Appendix 1: SDG 8); and (3) the promotion of inclusive and sustainable local industrialization (Appendix 1: SDG 9). Based on the above-introduced findings, our analysis suggests that while there are similarities between frugality and sustainability, it is still problematic to straightforwardly equate the two at the conceptual level.

Our literature review showed that there are no well-defined indicators for measuring the sustainability of an innovation in general and frugal innovation in particular. Therefore, our additional aim in this study was to develop indicators on the basis of sustainable development goals and to test the compatibility of those indicators. The indicators seem well-suited to assess the impacts of frugal innovations, coming from the energy and the water sectors, on sustainability. Nevertheless, we recognize that our indicator set would probably encounter the need for alteration if applied to the analysis of other types of frugal innovations. Additionally, we acknowledge that the results of our analysis are based on secondary data that cannot be considered indisputable or exhaustive. Rather, our results provide an initial understanding of how frugal innovation can influence sustainability and how the sustainability of frugal innovations can be studied.

\section{Conclusions}

The aspects of the sustainability of frugal innovations have not been addressed in the literature in a systematic manner. This article is a first step in that direction. The indicators developed for this study help to evaluate the sustainability of frugal innovations in ecological, social and economic dimensions. However, readers should be cautious with the generalization of our methodology and the findings. There are numerous aspects to frugal innovations that make their objective evaluation or comparison a highly demanding task. For example, the investigated energy production solutions seem to promote sustainable development particularly in environmental and economic dimensions since they reduce the need to consume non-renewable fuel consumption, thereby saving related expenses. However, it would be an exaggeration to say that these types of solutions are indisputably the most sustainable solutions in all situations. Energy solutions must always be evaluated in the local context relating to other possible options.

The same reasoning applies to water solutions. For example, in small rural villages in developing countries, a central water purification system would benefit a larger number of people than the single purification solutions studied here. In light of this observation, we note that a centralized system would be more sustainable for long-term development, although we must acknowledge that centralized systems are currently unattainable solutions in certain regions. Thus, in those situations, the evaluation of sustainability must be conducted from different perspectives. In fact, in developing countries, the relevance of any technology that provides access to water or energy is typically a local question, depending on the resources available, local environmental factors, geography and the culture of a particular area. For example, small solar lanterns are an important improvement for private households and small-scale entrepreneurs, but their significance for sustainability may be slim.

There are several avenues for future research. First, our study addressed only energy and water sectors; comparative evaluations between frugal innovations operating in different sectors would enhance the understanding about sustainability from a broader perspective. Second, it is not clear how to measure the sustainability of different frugal innovations. Should they be assessed against current local solutions or in relation to the technologically best available solutions? For example, larger mini-power plants for the distribution of electricity to a cluster of villages and centralized 
mini-water treatment plants could be more resource-efficient and sustainable [39]. However, this could compromise inclusive employment (Appendix 1: SDG 8). Moreover, operationally, gasifiers are vulnerable to a multitude of problems [44], meaning that there might be a need for stronger global partnerships for technological and sustainable development (Appendix 1: SDG 17). Whether conventional innovations and frugal innovations should be measured by the same parameters and scales is an important issue to consider. Third, it is unclear how the material efficiency of local solutions should be measured. Obviously, a lifecycle perspective should be included, but the question is how to operationalize it into the comparative analyses of cases whose lifecycles are not comparable. Fourth, development funding often emphasizes sustainable development, but the extent to which such funding contributes to sustainability is not always clear. Consequently, we need better tools to analyze the relations between frugal innovations and sustainable development.

Acknowledgments: We thank two anonymous reviewers for their valuable comments on an earlier versions of this article. The New Global project (newglobal.aalto.fi) by The Finnish Funding Agency for Innovation (TEKES) has funded this research and is gratefully acknowledged.

Author Contributions: The first authorship of this article has been shared between the first three authors who have contributed equally. The initial idea for the paper came from Mokter Hossain. Jarkko Levänen, Mokter Hossain and Tatu Lyytinen had the main responsibility for the research design and writing the article, with others contributing to it. Anne Hyvärinen had the main responsibility for the analyses of water solutions, and she also wrote major parts related to those, while Sini Numminen had the main responsibility for the SELCO analysis, and she also wrote major parts related to it. Tatu Lyytinen had the main responsibility for the HPS analysis and the related text. Minna Halme and Jarkko Levänen developed the indicators for the analysis, and Minna Halme contributed significantly to the clarification of the structure of the article and the identification of its key results. All authors contributed to and agreed with the final version of the article.

Conflicts of Interest: The authors declare no conflict of interest.

\section{Appendix 1}

Table A1. Sustainable Development Goals (SDGs) as accepted by the UN General Assembly in September 2015.

\begin{tabular}{|c|c|}
\hline & Sustainable Development Goals \\
\hline Goal 1 & End poverty in all its forms everywhere \\
\hline Goal 2 & $\begin{array}{l}\text { End hunger, achieve food security and improved nutrition and promote } \\
\text { sustainable agriculture }\end{array}$ \\
\hline Goal 3 & Ensure healthy lives and promote well-being for all at all ages \\
\hline Goal 4 & $\begin{array}{l}\text { Ensure inclusive and equitable quality education and promote lifelong learning } \\
\text { opportunities for all }\end{array}$ \\
\hline Goal 5 & Achieve gender equality and empower all women and girls \\
\hline Goal 6 & Ensure availability and sustainable management of water and sanitation for all \\
\hline Goal 7 & Ensure access to affordable, reliable, sustainable and modern energy for all \\
\hline Goal 8 & $\begin{array}{l}\text { Promote sustained, inclusive and sustainable economic growth, full and } \\
\text { productive employment and decent work for all }\end{array}$ \\
\hline Goal 9 & $\begin{array}{l}\text { Build resilient infrastructure, promote inclusive and sustainable industrialization } \\
\text { and foster innovation }\end{array}$ \\
\hline Goal 10 & Reduce inequality within and among countries \\
\hline Goal 11 & Make cities and human settlements inclusive, safe, resilient and sustainable \\
\hline Goal 12 & Ensure sustainable consumption and production patterns \\
\hline Goal 13 & Take urgent action to combat climate change and its impacts \\
\hline Goal 14 & $\begin{array}{l}\text { Conserve and sustainably use the oceans, seas and marine resources for } \\
\text { sustainable development }\end{array}$ \\
\hline Goal 15 & $\begin{array}{l}\text { Protect, restore and promote sustainable use of terrestrial ecosystems, sustainably } \\
\text { manage forests, combat desertification, and halt and reverse land degradation } \\
\text { and halt biodiversity loss }\end{array}$ \\
\hline Goal 16 & $\begin{array}{l}\text { Promote peaceful and inclusive societies for sustainable development, provide } \\
\text { access to justice for all and build effective, accountable and inclusive institutions } \\
\text { at all levels }\end{array}$ \\
\hline Goal 17 & $\begin{array}{l}\text { Strengthen the means of implementation and revitalize the global partnership for } \\
\text { sustainable development }\end{array}$ \\
\hline
\end{tabular}




\section{Appendix 2}

Table A2. Evaluation tables.

\begin{tabular}{|c|c|c|c|}
\hline \multicolumn{4}{|c|}{ Tata Swach Water Filter } \\
\hline Indicator & Points & Refs. & Supporting Arguments \\
\hline \multicolumn{4}{|l|}{ Ecological } \\
\hline $\begin{array}{l}\text { Is the frugal innovation more energy } \\
\text { efficient than the existing solution? }\end{array}$ & + & {$[40,41]$} & $\begin{array}{l}\text { "Devices required no electricity or pressurized water input } \\
\text { (operating by gravity only)." [40] } \\
\text { "Although devices did measurably improve water quality, especially } \\
\text { early in testing, reductions in key microbes and microspheres did } \\
\text { not indicate that technologies could meet international minimum } \\
\text { standards for drinking water treatment"; "Tata Swach requires } \\
\text { neither running water nor electricity nor boiling." [41] }\end{array}$ \\
\hline $\begin{array}{l}\text { Is the frugal innovation more material } \\
\text { efficient, e.g., recyclable or reusable, than } \\
\text { the existing solution? }\end{array}$ & - & {$[30,32]$} & $\begin{array}{l}\text { "Replaceable filters, available for } 3000 \text { litre and } 1500 \text { litre } \\
\text { purification capacity, otherwise the system is reusable." [30] } \\
\text { "Built around a bulb-like water purifier made of natural elements } \\
\text { like rice husk ash" [32] }\end{array}$ \\
\hline $\begin{array}{l}\text { Is the frugal innovation more climate } \\
\text { neutral than the existing solution? }\end{array}$ & + & $\mathrm{N} / \mathrm{A}$ & See analysis in Section 3.1.2. \\
\hline \multicolumn{4}{|l|}{ Social } \\
\hline $\begin{array}{l}\text { Does the frugal innovation help to fulfill } \\
\text { basic necessities, such as water, food } \\
\text { or shelter? }\end{array}$ & 0 & [39] & $\begin{array}{l}\text { "Although devices did measurably improve water quality, especially } \\
\text { early in testing, reductions in key microbes and microspheres did } \\
\text { not indicate that technologies could meet international minimum } \\
\text { standards for drinking water treatment." [39] }\end{array}$ \\
\hline $\begin{array}{l}\text { Does the frugal innovation enable better } \\
\text { health or improve access to education? }\end{array}$ & 0 & {$[40,41]$} & $\begin{array}{l}\text { "Although devices did measurably improve water quality, especially } \\
\text { early in testing, reductions in key microbes and microspheres did } \\
\text { not indicate that technologies could meet international minimum } \\
\text { standards for drinking water treatment." [40] } \\
\text { "Tata Swach mobile vans are visiting various cities to create } \\
\text { awareness about safe and healthy drinking water." [41] }\end{array}$ \\
\hline $\begin{array}{l}\text { Does the frugal innovation increase the } \\
\text { inclusion of marginalized people in } \\
\text { society and/or equality between } \\
\text { its members? }\end{array}$ & - & [38] & $\begin{array}{l}\text { "... targeted at poor, rural households that have no electricity or } \\
\text { running water." [38] }\end{array}$ \\
\hline \multicolumn{4}{|l|}{ Economic } \\
\hline $\begin{array}{l}\text { Does the use of frugal innovation release } \\
\text { the time resources of the users for } \\
\text { other purposes? }\end{array}$ & + & $\mathrm{N} / \mathrm{A}$ & See analysis in Section 3.3.2. \\
\hline $\begin{array}{l}\text { Does the use of the frugal innovation } \\
\text { increase the income of the user or save } \\
\text { them money? }\end{array}$ & 0 & $\mathrm{~N} / \mathrm{A}$ & See analysis in Section 3.3.2. \\
\hline $\begin{array}{l}\text { Does the frugal innovation create new } \\
\text { jobs and/or new enterprises? }\end{array}$ & 0 & $\mathrm{~N} / \mathrm{A}$ & See analysis in Section 3.3.2. \\
\hline \multicolumn{4}{|c|}{ Unilever Pureit Water Filter } \\
\hline Indicator & Points & Refs. & Supporting Arguments \\
\hline \multicolumn{4}{|l|}{ Ecological } \\
\hline $\begin{array}{l}\text { Is the frugal innovation more energy } \\
\text { efficient than the existing solution? }\end{array}$ & + & [29] & $\begin{array}{l}\text { "... the unit was designed to operate without electricity or other } \\
\text { power and without a piped-in water supply." [29] }\end{array}$ \\
\hline $\begin{array}{l}\text { Is the frugal innovation more material } \\
\text { efficient, e.g., recyclable or reusable, than } \\
\text { the existing solution? }\end{array}$ & - & $\mathrm{N} / \mathrm{A}$ & See analysis in Section 3.1.2. \\
\hline $\begin{array}{l}\text { Is the frugal innovation more climate } \\
\text { neutral than the existing solution? }\end{array}$ & + & $\mathrm{N} / \mathrm{A}$ & See analysis in Section 3.1.2. \\
\hline \multicolumn{4}{|l|}{ Social } \\
\hline $\begin{array}{l}\text { Does the frugal innovation help to fulfill } \\
\text { basic necessities, such as water, food } \\
\text { or shelter? }\end{array}$ & + & [29] & $\begin{array}{l}\text { "... treatment unit is effective under controlled circumstances in } \\
\text { removing or inactivating a range of microbial indicators of faecal } \\
\text { contamination." "The geometric mean reductions met the } \\
\text { requirements for a microbial water purifier prescribed by the EPA } \\
\text { protocol." [29] }\end{array}$ \\
\hline $\begin{array}{l}\text { Does the frugal innovation enable better } \\
\text { health or improve access to education? }\end{array}$ & 0 & [29] & $\begin{array}{l}\text { "The geometric mean reductions met the requirements for a } \\
\text { microbial water purifier prescribed by the EPA protocol." [29] }\end{array}$ \\
\hline $\begin{array}{l}\text { Does the frugal innovation increase the } \\
\text { inclusion of marginalized people in } \\
\text { society and/or equality between } \\
\text { its members? }\end{array}$ & - & [40] & $\begin{array}{l}\text { "is still too expensive for most of the base-of-the-pyramid } \\
\text { consumers" [40] }\end{array}$ \\
\hline \multicolumn{4}{|l|}{ Economic } \\
\hline $\begin{array}{l}\text { Does the use of frugal innovation release } \\
\text { the time resources of the users for } \\
\text { other purposes? }\end{array}$ & + & $\mathrm{N} / \mathrm{A}$ & See analysis in Section 3.3.2. \\
\hline $\begin{array}{l}\text { Does the use of the frugal innovation } \\
\text { increase the income of the user or save } \\
\text { them money? }\end{array}$ & 0 & $\mathrm{~N} / \mathrm{A}$ & See analysis in Section 3.3.2. \\
\hline $\begin{array}{l}\text { Does the frugal innovation create new } \\
\text { jobs and/or new enterprises? }\end{array}$ & 0 & $\mathrm{~N} / \mathrm{A}$ & See analysis in Section 3.3.2. \\
\hline
\end{tabular}


Table A2. Cont.

\begin{tabular}{|c|c|c|c|}
\hline \multicolumn{4}{|c|}{ Selco } \\
\hline Indicator & Points & Refs. & Supporting Arguments \\
\hline \multicolumn{4}{|l|}{ Ecological } \\
\hline \multirow{2}{*}{$\begin{array}{l}\text { Is the frugal innovation more energy } \\
\text { efficient than the existing solution? }\end{array}$} & \multirow[t]{2}{*}{+} & \multirow[t]{2}{*}[37,45]{} & $\begin{array}{l}\text { "Being a non-polluting source of energy, solar lights contribute to } \\
\text { environmental benefits as and when they replace other energy } \\
\text { sources such as firewood and kerosene. However, this impact is yet } \\
\text { to be quantified" [37] }\end{array}$ \\
\hline & & & $\begin{array}{l}\text { "Without [grid supplied] power, they depend on candles and } \\
\text { kerosene lamps for lighting. About } 400 \text { million Indians lack reliable } \\
\text { electricity" [45] }\end{array}$ \\
\hline $\begin{array}{l}\text { Is the frugal innovation more material } \\
\text { efficient, e.g., recyclable or reusable, than } \\
\text { the existing solution? }\end{array}$ & 0 & [26] & $\begin{array}{l}\text { "As part of the business model, spent batteries and CFLs are } \\
\text { collected and sent back to the manufacturers for recycling." [26] }\end{array}$ \\
\hline $\begin{array}{l}\text { Is the frugal innovation more climate } \\
\text { neutral than the existing solution? }\end{array}$ & + & [25] & $\begin{array}{l}\text { "By 2007, SELCO had sold 71,000 solar home systems, serving } \\
\text { around 325,000 people. Typical family uses about } 120 \text { litres/year of } \\
\text { kerosene for lighting, so systems installed replace about } 8.5 \text { million } \\
\text { litres/year of kerosene, and the emission of about } 22,000 \text { tonnes/year } \\
\text { of } \mathrm{CO}_{2} \text { ". [25] }\end{array}$ \\
\hline \multicolumn{4}{|r|}{ 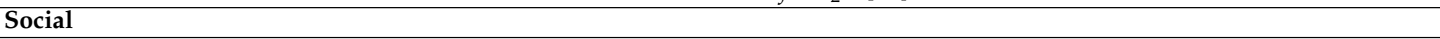 } \\
\hline $\begin{array}{l}\text { Does the frugal innovation help to fulfill } \\
\text { basic necessities, such as water, food } \\
\text { or shelter? }\end{array}$ & + & $\mathrm{N} / \mathrm{A}$ & See analysis in Section 3.2.1. \\
\hline \multirow{3}{*}{$\begin{array}{l}\text { Does the frugal innovation enable better } \\
\text { health or improve access to education? }\end{array}$} & \multirow{3}{*}{+} & \multirow{3}{*}[25,45,46]{} & $\begin{array}{l}\text { "The immediate benefit of using a PV system is that the use of } \\
\text { smoky, dangerous kerosene lamps is minimised" [25] }\end{array}$ \\
\hline & & & $\begin{array}{l}\text { "There was no current at night," said Varshitha Shivanna, 15, who } \\
\text { lives in the house with her grandparents. During evening power } \\
\text { cuts, she used to rely on candles. But now, with solar light, "we can } \\
\text { write till how much time we want. We are writing homework till } \\
\text { 11." [45] }\end{array}$ \\
\hline & & & $\begin{array}{l}\text { "Providing a reliable source of electricity has resulted in a better } \\
\text { quality of life. Longer working hours in better quality light has led } \\
\text { to higher incomes and better education while lesser dependence on } \\
\text { conventional fuels has improved health conditions." [46] }\end{array}$ \\
\hline \multirow[b]{2}{*}{$\begin{array}{l}\text { Does the frugal innovation increase the } \\
\text { inclusion of marginalized people in } \\
\text { society and/or equality between } \\
\text { its members? }\end{array}$} & \multirow[b]{2}{*}{+} & \multirow[b]{2}{*}[37,47,48]{} & $\begin{array}{l}\text { "SELCO India is a Bangalore-based social enterprise that makes } \\
\text { solar lighting technology accessible to the economically } \\
\text { impoverished people in India." [37] }\end{array}$ \\
\hline & & & $\begin{array}{l}\text { "Linking income generating activities with energy services has } \\
\text { improved the quality of life for several members of underserved } \\
\text { households by providing affordable channels to procure the } \\
\text { technology thereby increasing work hours and hence } \\
\text { productivity." [48] }\end{array}$ \\
\hline \multicolumn{4}{|l|}{ Economic } \\
\hline \multirow{2}{*}{$\begin{array}{l}\text { Does the use of frugal innovation release } \\
\text { the time resources of the users for } \\
\text { other purposes? }\end{array}$} & \multirow[b]{2}{*}{+} & \multirow[b]{2}{*}[37,46]{} & $\begin{array}{l}\text { "Moreover, there will be non-quantifiable benefits in terms of better } \\
\text { health, increased hours of study for the children as well as saving } \\
\text { time that is spent in procuring kerosene or sourcing } \\
\text { forest-wood." [37] }\end{array}$ \\
\hline & & & $\begin{array}{l}\text { "Linking income generating activities with energy services has } \\
\text { improved the quality of life for several members of underserved } \\
\text { households by providing affordable channels to procure the } \\
\text { technology thereby increasing work hours and hence } \\
\text { productivity." [46] }\end{array}$ \\
\hline $\begin{array}{l}\text { Does the use of the frugal innovation } \\
\text { increase the income of the user or save } \\
\text { them money? }\end{array}$ & + & [37] & $\begin{array}{l}\text { "An impact assessment study by World Resources Institute in } 2007 \\
\text { reported that } 86 \% \text { of SELCO's poor customers cited significant } \\
\text { savings in energy costs as their primary benefit of using SELCO } \\
\text { products" [37] }\end{array}$ \\
\hline $\begin{array}{l}\text { Does the frugal innovation create new } \\
\text { jobs and/or new enterprises? }\end{array}$ & + & [37] & $\begin{array}{l}\text { "SELCO's inclusive business model has led to the creation of } \\
\text { employment not only for its own employees but also for several } \\
\text { rural entrepreneurs who rent out solar lights to vendors and } \\
\text { institutions" [37] }\end{array}$ \\
\hline
\end{tabular}


Table A2. Cont.

\begin{tabular}{|c|c|c|c|}
\hline \multicolumn{4}{|c|}{ Husk Power System (HPS) } \\
\hline Indicator & Points & Refs. & Supporting Arguments \\
\hline \multicolumn{4}{|l|}{ Ecological } \\
\hline \multirow[t]{2}{*}{$\begin{array}{l}\text { Is the frugal innovation more energy } \\
\text { efficient than the existing solution? }\end{array}$} & \multirow[t]{2}{*}{+} & \multirow[t]{2}{*}[27,37,43,46]{} & $\begin{array}{l}\text { "All of the prevalent rice husk-based gasifier systems ran in what is } \\
\text { called the 'dual-fuel' mode of operation where the producer gas } \\
\text { produced by the gasifiers was used in conjunction with } 35 \%-50 \% \\
\text { diesel to power the diesel engines." [43] }\end{array}$ \\
\hline & & & $\begin{array}{l}\text { "Kerosene and diesel are both very expensive and the central grid, if } \\
\text { it exists in the village, is extremely unreliable." [46] }\end{array}$ \\
\hline $\begin{array}{l}\text { Does the frugal innovation help to fulfill } \\
\text { basic necessities, such as water, food } \\
\text { or shelter? }\end{array}$ & + & {$[27,34,36]$} & $\begin{array}{l}\text { "Villagers say that burglaries have reduced because of better } \\
\text { lighting at night, and the number of snakebites in each village } \\
\text { suddenly dropped to zero when the electricity came." [34] }\end{array}$ \\
\hline \multirow{3}{*}{$\begin{array}{l}\text { Does the frugal innovation enable better } \\
\text { health or improve access to education? }\end{array}$} & \multirow[t]{3}{*}{+} & \multirow[t]{3}{*}[24,34,35]{} & $\begin{array}{l}\text { "In } 2011 \text { HPS set up Husk Power University in partnership with } \\
\text { the Shell Foundation and the International Finance Corporation } \\
\text { (IFC). The university is a training program for mechanics and } \\
\text { mid-level managers." [34] }\end{array}$ \\
\hline & & & $\begin{array}{l}\text { "HPS helped around } 250 \text { students as part of its corporate social } \\
\text { responsibility through the Samta Samriddhi Foundation." [35] }\end{array}$ \\
\hline & & & "All employees were provided with a medical cover ... " [24] \\
\hline \multirow{2}{*}{$\begin{array}{l}\text { Does the frugal innovation increase the } \\
\text { inclusion of marginalized people in } \\
\text { society and/or equality between } \\
\text { its members? }\end{array}$} & \multirow[b]{2}{*}{+} & \multirow[b]{2}{*}[24,34,36,39]{} & $\begin{array}{l}\text { "Local women are employed in incense stick-making, thereby } \\
\text { reinforcing the development link with the community." [39] }\end{array}$ \\
\hline & & & $\begin{array}{l}\text { "HPS recruited locals with modest education levels who would be } \\
\text { considered unemployable by many companies and trained them to } \\
\text { operate load machines, work as fee collectors and loaders." [24] }\end{array}$ \\
\hline \multirow{2}{*}{$\begin{array}{l}\text { Does the use of frugal innovation release } \\
\text { the time resources of the users for } \\
\text { other purposes? }\end{array}$} & \multirow[t]{2}{*}{+} & \multirow[t]{2}{*}[27,36,42]{} & $\begin{array}{l}\text { "Productivity increases as fuel doesn't have to be procured on foot } \\
\text { from cities" [42] }\end{array}$ \\
\hline & & & $\begin{array}{l}\text { "Electricity allowed shopkeepers to work longer hours and farmers } \\
\text { to irrigate more land; the lights allowed the students to study late } \\
\text { into the evening" [27] }\end{array}$ \\
\hline \multirow{3}{*}{$\begin{array}{l}\text { Does the use of the frugal innovation } \\
\text { increase the income of the user or save } \\
\text { them money? }\end{array}$} & \multirow{3}{*}{+} & \multirow{3}{*}[23,33,35,36]{} & $\begin{array}{l}\text { "... about } 400 \text { \$ per month is recycled into the local economy." } \\
\text { [36] "The rice mills supplying husk to the power plant receive about } \\
25 \text { \$ per tonne of husk" [36] }\end{array}$ \\
\hline & & & $\begin{array}{l}\text { "HPS offers them electricity at a monthly cost of } \$ 1.8 \text { for villagers, } \\
\text { thus the saving is close to one-third." [23] }\end{array}$ \\
\hline & & & $\begin{array}{l}\text { "He previously paid Rs. } 1700 \text { per month to run a diesel generator to } \\
\text { light the hostel from } 6 \text { to } 9 \mathrm{pm} \text {, but now pays Rs. } 1200 \text { a } \\
\text { month" [33] }\end{array}$ \\
\hline \multirow{2}{*}{$\begin{array}{l}\text { Does the frugal innovation create new } \\
\text { jobs and/or new enterprises? }\end{array}$} & \multirow[b]{2}{*}{+} & \multirow[b]{2}{*}[23,27,36,42]{} & $\begin{array}{l}\text { "HPS employs } 350 \text { people directly, and two independent plant } \\
\text { owner-operators have created eight additional jobs between them. } \\
\text { Close to } 300 \text { of these employees are from the villages HPS } \\
\text { serves." [42] }\end{array}$ \\
\hline & & & $\begin{array}{l}\text { "HPS trained around } 200 \text { women in incense stick making in 2010." } \\
\text { [36] "The decision of local fabrication of the equipment as opposed } \\
\text { to buying from a manufacturer has turned out to be a smart move as } \\
\text { this has reduced the capital cost of the plant." [36] }\end{array}$ \\
\hline
\end{tabular}

\section{References}

1. Zeschky, M.; Widenmayer, B.; Gassmann, O. Frugal innovation in emerging markets. Res.-Technol. Manag. 2011, 54, 38-45.

2. Zeschky, M.; Winterhalter, S.; Gassmann, O. From Cost to Frugal and Reverse Innovation: Mapping the Field and Implications for Global Competitiveness. Res.-Technol. Manag. 2014, 57, 20-27.

3. Simula, H.; Hossain, M.; Halme, M. Frugal and Reverse Innovations-Quo Vadis? Curr. Sci. 2015, 109, 1-6. [CrossRef] 
4. London, T.; Hart, S.T. Reinventing strategies for emerging markets: Beyond the Transnational Model. J. Int. Bus. Stud. 2004, 35, 350-370. [CrossRef]

5. Bound, K.; Thornton, I.W. Our Frugal Future: Lessons from India's Innovation System; Nesta: London, UK, 2012. Available online: http://www.nesta.org.uk/sites/default/files/our_frugal_future.pdf (accessed on 14 July 2015).

6. Govindarajan, V.; Ramamurti, R. Delivering world-class health care, affordably. Harv. Bus. Rev. 2013, 91, 117-122.

7. Rao, B.C. How disruptive is frugal? Technol. Soc. 2013, 35, 65-73. [CrossRef]

8. Tapia-Fonllem, C.; Corral-Verdugo, V.; Fraijo-Sing, B.; Durón-Ramos, M.F. Assessing Sustainable Behavior and its Correlates: A Measure of Pro-Ecological, Frugal, Altruistic and Equitable Actions. Sustainability 2013, 5, 711-723. [CrossRef]

9. Manno, J.P. Looking for a Silver Lining: The Possible Positives of Declining Energy Return on Investment (EROI). Sustainability 2011, 3, 2071-2079. [CrossRef]

10. Radjou, N.; Prabhu, J. Frugal Innovation: How to Do More with Less, 1st ed.; Profile Books Ltd.: London, UK, 2014.

11. Gatto, M. Sustainability: Is it a well-defined concept? Ecol. Appl. 1995, 5, 1181-1183.

12. Phillis, Y. A.; Andriantiatsaholiniaina, L.A. Sustainability: An ill-defined concept and its assessment using fuzzy logic. Ecol. Econ. 2001, 37, 435-456. [CrossRef]

13. World Commission on Environment and Development (WCED). Our Common Future; Oxford University Press: Oxford, UK, 1987.

14. Sustainable Development Goals. Available online: https://sustainabledevelopment.un.org/ (accessed on 14 September 2015).

15. Pina e Cunha, M.; Rego, A.; Oliveira, P.; Rosado, P.; Habib, N. Product Innovation in Resource-Poor Environments: Three Research Streams. J. Prod. Innov. Manag. 2013, 31, 202-210. [CrossRef]

16. Bhatti, Y. What Is Frugal, What Is Innovation? Towards a Theory of Frugal Innovation. Available online: http://papers.ssrn.com/sol3/papers.cfm?abstract_id=2005910 (accessed on 17 November 2015).

17. Radjou, N.; Prabhu, J.; Ahuja, S. Jugaad Innovation: Think Frugal, Be Flexible, Generate Breakthrough Growth, 1st ed.; John Wiley \& Sons: San Francisco, CA, USA, 2012.

18. Angot, J.; Plé, L. Serving poor people in rich countries: The bottom-of-the-pyramid business model solution. J. Bus. Strategy 2015, 36, 3-15. [CrossRef]

19. Basu, R.R.; Banerjee, P.M.; Sweeny, E.G. Frugal Innovation: Core Competencies to Address Global Sustainability. J. Manag. Glob. Sustain. 2013, 1, 63-82. [CrossRef]

20. Bhatti, Y.A.; Ventresca, M. The Emerging Market for Frugal Innovation: Fad, Fashion, or Fit? Working Paper 2012. Available online: http:/ / papers.ssrn.com/sol3/papers.cfm?abstract_id=2005983 (accessed on 25 September 2015).

21. Horn, C.; Brem, A. Strategic directions on innovation management-A conceptual framework. Manag. Res. Rev. 2013, 36, 939-954. [CrossRef]

22. Brem, A.; Ivens, B. Do Frugal and Reverse Innovation Foster Sustainability? Introduction of a Conceptual Framework. J. Technol. Manag. Grow. Econ. 2013, 4, 31-50.

23. Tranfield, D.; Denyer, D.; Smart, P. Towards a methodology for developing evidence informed management knowledge by means of systematic review. Br. J. Manag. 2003, 14, 207-222. [CrossRef]

24. Gupta, R.; Pandit, A.; Nirjar, A.; Gupta, P. Husk Power Systems: Bringing Light to Rural India and Tapping Fortune at the Bottom of the Pyramid. Asian J. Manag. Cases 2013, 10, 129-143. [CrossRef]

25. Case Study Summary: SELCO Solar Pvt Ltd, India, 2009. Available online: https://www.ashden.org/ files/SELCO\%20full_0.pdf (accessed on 19 September 2015).

26. SELCO Solar Lights Rural Lives. Available online: http://www.treehugger.com/renewable-energy/ selco-solar-lights-rural-lives.html (accessed on 19 September 2015).

27. Case Study Summary: Husk Power Systems India. Available online: https://www.ashden.org/ files/Husk\%20winner.pdf (accessed on 14 July 2015).

28. Bhathena, Z.P.; Shrivastava, S.; Londhe, P.; Brown, J. Microbiological performance of novel household water treatment devices in India. Water Sci. Technol. Water Supply 2014, 14, 91-98. [CrossRef]

29. Clasen, T.; Nadakatti, S.; Menon, S. Microbiological performance of a water treatment unit designed for household use in developing countries. Trop. Med. Int. Health 2006, 11, 1399-1405. [CrossRef] [PubMed] 
30. Tata Swach Products. Available online: http://www.tataswach.com/products (accessed on 13 July 2015).

31. Why Do You Need a Water Purifier? Available online: http://www.pureitwater.com/IN/products (accessed on 13 July 2015).

32. Tata Chemicals launches Tata Swach. Available online: http://www.tatachemicals.com/media/releases/ 200912dec/20091207.htm\#.VflK5Z2qqko (accessed on 13 July 2015).

33. Clasen, T.; McLaughlin, C.; Nayaar, N.; Boisson, S.; Gupta, R.; Desai, D.; Shah, N. Microbiological Effectiveness and Cost of Disinfecting Water by Boiling in Semi-urban India. Am. J. Trop. Med. Hyg. 2008, 79, 407-413. [PubMed]

34. Empowering Bihar: Case Studies for Bridging the Energy Deficit and Driving Change. Available online: http://www.greenpeace.org/india/Global/india/report/Empowering-Bihar.pdf (accessed on 14 July 2015).

35. Energy for the Masses: Husk Power Helps Fuel India. Available online: http://www.ecomagination.com/ energy-for-the-masses-husk-power-helps-fuel-india (accessed on 11 June 2015).

36. Husk Power Systems: Lighting up the Indian Rural Lives. Available online: http://oikos-international.org/ wp-content/uploads/2013/11/oikos_Cases_2013_Husk_Power.pdf (accessed on 14 July 2015).

37. SELCO: Solar Lighting for the Poor. Available online: http://www.growinginclusivemarkets.org/media/ cases/India_SELCO_2011.pdf (accessed on 17 September 2015).

38. Tata Swach's Mobile vans Create Awareness about Safe Drinking Water Prior to the Monsoon Season. Available online: http://www.tatachemicals.com/media/releases/201206june/tata_swach_mobile_ vans.html\#.VfAkZi757Hs (accessed on 9 September 2015).

39. Bhattacharyya, S.C. Viability of off-grid electricity supply using rice husk: A case study from South Asia. Biomass Bioenergy 2014, 68, 44-54. [CrossRef]

40. Ahlstrom, D. Innovation and Growth: How Business Contributes to Society. Acad. Manag. Perspect. 2010, 24, 11-24. [CrossRef]

41. Waterworks Pilot Gives 75,000 Access to Clean Water. Available online: http://www.unilever.com.vn/ media-centre/news/waterworks-pilot.aspx (accessed on 18 September 2015).

42. From Darkness to Light. Available online: http://www.thehindu.com/features/magazine/from-darknessto-light/article5124148.ece (accessed on 13 July 2015).

43. Inclusive Business Models: Guide to the Inclusive Business Models in IFC Portfolio: Client Case Studies. Available online: http://www.ifc.org/wps/wcm/connect/3af114004cc75b599498b59ec86113d5/ Pub_002_IFC_2011_Case\%2BStudies.pdf?MOD=AJPERES (accessed on 14 July 2015).

44. Microgrids for Rural Electrification: A Critical Review of Best Practices Based on Seven Case Studies. Available online: https://rael.berkeley.edu/wp-content/uploads/2015/04/MicrogridsReportEDS.pdf (accessed on 25 September 2015).

45. Bringing Light to Rural Homes and Areas. Available online: http://www.deccanherald.com/ content/ 93761/bringing-light-rural-homes-areas.html (accessed on 11 September 2015).

46. SELCO. Available online: http://www.selco-india.com/pdfs/corporate_brochure_selco.pdf (accessed on 19 September 2015).

47. Sun Dialling. Available online: http://blogcms.outlookindia.com/article_v3.aspx?artid=261397 (accessed on 19 September 2015).

48. Impact. Available online: http://www.selco-india.com/impact.html (accessed on 19 September 2015).

(C) 2015 by the authors; licensee MDPI, Basel, Switzerland. This article is an open access article distributed under the terms and conditions of the Creative Commons by Attribution (CC-BY) license (http://creativecommons.org/licenses/by/4.0/). 